\title{
Formação de Biofilmes por Salmonella Sp. Isoladas de Esteiras Condutoras de Frango em Salas de Cortes de Plantas Processadoras de Aves
}

Rosangela Estel Ziech (I), Camila Lampugnani (I), Ana Paula Perin (I), Cibeli Viana (I), Vera Lúcia Mores Rall (II), Luciano dos Santos Bersot (I)

(I) UFPR - Universidade Federal do Paraná - Setor Palotina (Rua Pioneiro, 2153, Bairro Jardim Dallas, Palotina, PR), (II) UNESP - Universidade Estadual Paulista "Júlio de Mesquita Filho" (Distrito de Rubião Junior s/n, CP 510,CEP:18618-970, Botucatu, SP)

\section{Resumo}

A formação de biofilmes por Salmonella sp. é uma preocupação para a indústria de alimentos, devido à sua permanência nas superfícies e risco de contaminação constante do produto. Nas salas de corte das indústrias de abate e processamento de aves é comum o uso de esteiras condutoras dos produtos. Nessas esteiras usualmente a higiene operacional é realizada com aspersão de água sob pressão, sendo importante se obter informações sobre a ocorrência de patógenos, como Salmonella, e sua capacidade de formar biofilmes nestas superfícies. Neste estudo foi avaliada a relação da formação de biofilmes em poliestireno e a presença de genes associados ao biofilme com a origem das amostras. As 98 cepas testadas eram originárias de quatro salas de cortes de plantas processadoras de aves, de esteiras modulares com água (MCA, $n=23$ ) e sem água (MSA, n=27); lisas com água (LCA, n=21) e sem água (LSA, n=27). Foi avaliada a formação de biofilmes em placas de poliestireno após incubação de $108 \mathrm{UFC} / \mathrm{mL}$ de cada cepa em caldo Luria Betani por $96 \mathrm{~h}$ a $35^{\circ} \mathrm{C}$. A formação de biofilmes foi visualizada pela medida da absorbância em leitor de microplacas onde as cepas foram classificadas em fracamente, moderadamente e fortemente produtoras de biofilmes. A PCR foi realizada para pesquisa dos genes adrA e agfD relacionados aos componentes formadores da matriz dos biofilmes,

\footnotetext{
Referência:

Rosangela Estel Ziech, Camila Lampugnani, Ana Paula Perin, Cibeli Viana, Vera Lúcia Mores RalL, Luciano dos Santos Bersot.Formação de Biofilmes por Salmonella Sp. Isoladas de Esteiras Condutoras de Frango em Salas de Cortes de Plantas Processadoras de Aves. In: Anais do 12을 Congresso Latinoamericano de Microbiologia e Higiene de Alimentos - MICROAL 2014 [= Blucher Food Science Proceedings, num.1, vol.1]. São Paulo: Editora Blucher, 2014. 
celulose e fímbrias, respectivamente. Como controle positivo, foi utilizada a cepa de Salmonella Typhimirium ATCC 14028. A habilidade de formação de biofilmes em poliestireno foi classificada como fortemente somente em uma cepa oriunda de esteira LCA. Nas demais cepas, a habilidade de formação de biofilmes foi classificada como fracamente em $61 \%$ das provenientes de esteiras MCA, 70\% LSA, 74\% MSA e 76\% LCA. E foram moderadamente formadoras de biofilmes $19 \%$ das cepas de esteiras LCA, 26\% MSA, 30\% LSA e 39\% MCA. Apesar da alta frequência de cepas fracamente positivas, ambos os genes foram encontrados em todas as cepas. Contudo os genes pesquisados podem não ser os únicos envolvidos no processo de formação de biofilmes. Os resultados deste estudo atentam para a importância do isolamento de cepas com capacidade de formar biofilmes em superfícies de matadouros de aves, fato que pode incorrer em uma maior permanência desse micro-organismo na indústria e na sua consequente transferência para os alimentos.

Palavras-Chave: biofilmes, esteiras condutoras de cortes de frango, patógenos alimentares, Salmonella sp.

\section{Agência de Fomento:}

